GALVESTON ISLAND 
This page intentionally left blank. 
This page intentionally left blank. 


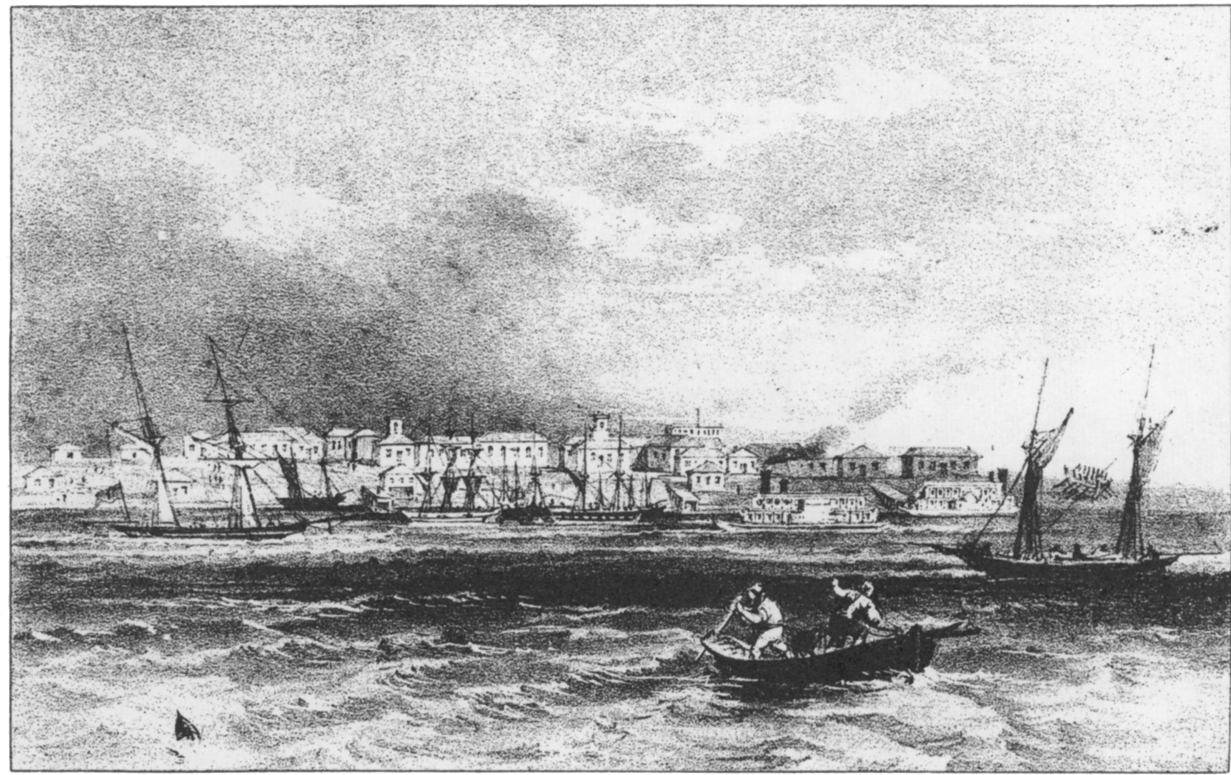




\section{GALVESTON ISLAND}

\section{Or, A FEW MONTHS OFF THE COAST OF TEXAS}

\section{The Journal of FRANCIS C. SHERIDAN 1839-1840}

Edited by WILLIS W. PRATT

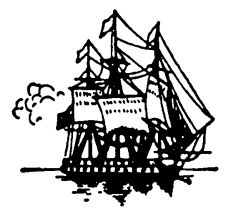

AUSTIN : I954

UNIVERSITY OF TEXAS PRESS 
Copyright () 1954 by the University of Texas Press

Copyright (c) renewed 1982

All rights reserved

Printed in the United States of America

Requests for permission to reproduce material from this work should be sent to:

Permissions

University of Texas Press

P.O. Box 7819

Austin, TX 78713-7819

http://utpress.utexas.edu/index.php/rp-form

Library of Congress Catalog Number 53-11770

ISBN 978-0-292-74170-6, paperback

ISBN 978-0-292-75586-4, library e-book

ISBN 978-0-292-75587-1, individual e-book 


\section{To the Trunk Makers \& Buttermen of Great Britain}

GENT $^{N}$ Aware as I am that the light ephemeral works of the day arrive into $y^{r}$ hands at last- $\&$ feeling that this work is but a bubble on the stream of literature-I am anxious by a dedication to conciliate $y^{r}$ feelings so far in my favour, that when wrapping up your wares, you will select these papers for the fresh in preference to the salt Butter-

[Francis C. Sheridan] 
This page intentionally left blank. 